\title{
Effects of varying intensity exercise on shortening and intracellular calcium in ventricular myocytes from streptozotocin (STZ)-induced diabetic rats
}

Frank Christopher Howarth · F. A. Almugaddum •

M. A. Qureshi · M. Ljubisavljevic

Published online: 13 June 2009

(C) Springer Science+Business Media, LLC. 2009

Erratum to: Mol Cell Biochem (2008) 317:161-167 DOI 10.1007/s11010-008-9844-z

In this article, the name of the last co-author is given as Ljubisavijevic M. Dr. Ljubisavljevic surname is misspelled.
His correct name should read "Ljubisavljevic M". Everything else in this article remains correct.

The online version of the original article can be found under doi: 10.1007/s11010-008-9844-z.

F. C. Howarth $(\varangle)$ · F. A. Almugaddum .

M. A. Qureshi · M. Ljubisavljevic

Department of Physiology, Faculty of Medicine \& Health

Sciences, United Arab Emirates University, P.O. Box 17666,

Al Ain, UAE

e-mail: chris.howarth@uaeu.ac.ae 